\title{
The Machnik Decree of 1936 and its Perception by the British Legation in Prague and the Foreign Office
}

\section{Lukáš NOVOTNÝ}

Katedra historických věd, Fakulta filozofická, Západočeská univerzita v Plzni

Department of Historical Sciences, Faculty of Philosophy and Arts, University of West Bohemia, Tylova 18, 30125 Plzeň, Czech Republic

novoluk@khv.zcu.cz

After First World War and in the 1920s, Great Britain and the Foreign Office held an optimistic view of the development between the Czech and German ethnics in Czechoslovakia, or, to be more accurate, the Foreign Office's initial scepticism regarding the new state shifted in the early 1920 s to become somewhat more favourable to Czechoslovakia. The British saw it as a rationally managed nation "with enlightened leaders lead by Tomáš Masaryk". ${ }^{1}$ In the 1930s, however, situation changed. Foreign Office began strengthening its view that the successor states, including Czechoslovakia, failed their mission to which they had committed after 1918, i.e. that they "hadn't brought peace and stability to Central Europe". ${ }^{2}$ While the previous decade was marked mainly by the search of a certain modus vivendi between Germans and the Czechoslovak government and by the cooperation of "activist" parties on the administration level after 1926; ${ }^{3}$ the 1930 s dealt with the impact of the economic crisis which hit hard even the German minority, and with the accession of Adolf Hitler to power in January 1933, which only intensified Czech-German ethnic divisions. ${ }^{4}$

1 Jindřich DEJMEK, Nenaplněné naděje. Politické a diplomatické vztahy Československa a Velké Británie (19181938), Praha 2003, 311. In 1928, British envoy Sir Ronald McLeay for example wrote that "despite various daily disputes between the Czech and most of the Germans there are no serious disputes in the states in political matters". Jindřich DEJMEK, Britská diplomacie, Československo a Sudetoněmecká strana, in: Moderní dějiny. Sborník k dějinám 19. a 20. století 9, 2001, 162.

2 Zdeněk KÁRNíK, České země v éře První republiky (1918-1938). Díl druhý. Československo a České země v krizi a ohrožení (1930-1935), Praha 2002, 392.

3 In 1926 Bund der Landwirte (BdL) and Deutsche christlichsoziale Volkspartei (DCV) joined the government lead by Antonín Švehla. In the 1920s, the German government avoided important confrontations with the Czechoslovak cabinet and did not support activities of Sudeten Germans with political subtext. The government rather focused "auf Unterstützung von 'apolitischen' Initiativen" [...]. Jaroslav Kučera, Minderheit im Nationalstaat. Die Sprachenfrage in den tschechisch-deutschen Beziehungen 1918-1938, München 1999, 99. German Foreign Minister Gustav Stresemann even refused to officially meet Sudeten German politicians in May 1926. Cf. Deutsche Gesandtschaftsberichte aus Prag. Innenpolitik und Minderheitenprobleme in der Ersten Tschechoslowakischen Republik (hereinafter referred only as Deutsche Gesandtschaftsberichte aus Prag), Teil II. Vom Kabinett Beneš bis zur ersten übernationalen Regierung unter Švehla 1921-1926. Berichte des Gesandten Dr. Walter Koch. Ausgewählt, eingeleitet und kommentiert von Manfred Alexander, Veröffentlichungen des Collegium Karolinum, Band 49/II, München 2004, Stresemanns Ablehnung eines Treffens mit sudetendeutschen Politikern, Berlin, den 4. Mai 1926, No. A 67, 768-769.

4 Cf. Mark CORNWALL, A Fluctuating Barometer: British Diplomatic Views of the Czech-German Relationship in Czechoslovakia, 1918-1938, in: Großbritannien, die USA und die böhmischen Länder 1848-1938, Eva SCHMIDT-HARTMANN - Stanley B. WINTERS (eds.), München 1991, 313. 
The parliamentary election of 1935 became an important milestone in the Czech-German relations of the 1930s. The first half of the year was fully characterized by the pre-election campaign. Sudetendeutsche Heimatfront (SHF) transformed into Sudetendeutsche Partei $(\mathrm{SdP}) .{ }^{5}$ The new party was preparing carefully for the election; it disposed of abundant funds both from Sudeten German businessmen and from the Reich. ${ }^{6}$ According to German envoy Walter Koch, the Czechoslovak government was hoping that it would cause problems to Henlein's movement by pressuring the SHF to rename as the SdP.7

The election brought a landslide victory of the SdP who, however got one parliamentary seat less than the second party in the election, the Agrarian party. This was due to the construction of the electoral system. The party leadership expected an invitation to join the government; the leaders based their hopes on the fact that the party had become the strongest political entity in the country and mainly on the crushing defeat of other German activist parties in the election (the Social Democrats, the Agrarians and the Christian Socials). In the end, the SdP was not invited to join the government. It was due to the fact that the party had made it absolutely clear it would not settle for minor concessions and it would insist on fundamental reforms of the ethnic organization of the Republic. That was a request the Czechoslovak political representation could not and would not accept.

After Adolf Hitler's accession to the post of Reich Chancellor the Czechoslovak Ministry of National Defence started to commission an intensified number of state contracts. It was obvious that businesses intending to bid for the contracts had to have employees who had been proven reliable or the state. In January 1936 the Ministry started to "send written calls to businesses intending to bid for state contracts, especially in the arms industry. The calls required the businesses to carry out certain ethnic measures" ${ }^{8}$ More specifically, the calls (from January 24 and 28) were addressed to eighteen companies, setting the ethnic composition of the company as a condition of a prospective state contract. Even though the calls were probably not issued on personal orders of the Agrarian party's Minister of National Defence, František Machník, ${ }^{9}$ his name remained connected to the affair once for all. Had

5 The then legislation only allowed political parties to stand for elections. SHF, however, was a movement, and could therefore not take part in the election. In addition to that, the word "Party" made a more democratic impression.

6 Jaroslav KUČERA notes that the SDP received a total of 331, 711 Reichmarks for its electoral activities. Jaroslav KUČERA, Mezi Wilhelmstraßse a Thunovskou. Finanční podpora Německé říše Sudetoněmecké straně v letech 1935-1938, in: Český časopis historický 95, 1997, 2, 392.

7 Deutsche Gesandtschaftsberichte aus Prag, Teil IV. Vom Vorabend der Machtergreifung in Deutschland bis zum Rücktritt von President Masaryk 1933-1935. Berichte des Gesandten Koch, der Konsuln von Bethusy-Huc, von Druffel, von Pfeil und des Gesandtschaftsrates von Stein. Ausgewählt, eingeleitet und kommentiert von Heidrun und Stephan Dolezel, Veröffentlichungen des Collegium Karolinum, Band 49/IV, München 1991, Gründung einer neuen nationalen, oppositionellen Sudetendeutschen Wahlgruppe, Deutsche Gesandtschaft an das Auswärtige Amt, Prag, den 2. Mai 1935, No. 117, 243-245.

8 Lukáš KOPECKÝ, František MACHNÍK, život agrárního politika a ministra národní obrany (unpublished M.A. thesis), České Budějovice 2011, 51.

9 Antonin Klimek comments on him as a weak person and a puppet in the hands of the President, who "referring to his quality as the Commander-in-Chief, interfered ever more intensely with the defence forces issues, even though he knew little about them". Antonín KLIMEK - Petr HOFMAN, Velké dějiny zemí Koruny české, svazek XIV., 1929-1938, Praha - Litomyšl 2002, 425. 
the companies not be reconciled with the set rules, the Ministry would have cancelled their agreement immediately. The businesses were above all to modify the ethnic proportions of their employees so that "daß 1. die Zahl der Beamten tschsl. Nationalität mindestens dem prozentuellen Verhältnis der im Unternehmen beschäftigten Arbeiter tschsl. Nationalität entspreche, 2. die Zahl der Arbeiter tschsl. Nationalität mindestens dem nationalen Verhältnis der Bevölkerung jener Gegend entspreche, in der das Unternehmen seinen Sitz hat. Weiters werden Sie", the document stated, "in kürzester Zeit die ausländischen Angestellten durch inländische Kräfte tschsl. Nationalität ersetzen und kein Personal (Beamte und Arbeiter) beschäftigten, das sich zu staatsfeindlichen Parteien bekennt" ${ }^{10}$

Unquestionably those written calls meant discrimination mainly against Czech Germans, "because the fortifications were built in the territories they populated and that was a way to minimize the chances their businesses could profit from the state contracts" ${ }^{11}$ It was also a violation of the Minority Treaty, in which Czechoslovakia had guaranteed equal rights to all minorities. There were also intense reactions by the Germen press in Czechoslovakia, e.g. Prager Tagblatt, Deutsche Presse or Sozialdemokrat who strongly denounced the whole situation. ${ }^{12}$

Naturally, the British Legation paid close attention to the Czech-German relations, at least until the end of 1935, when the SdP's leader Konrad Henlein visited London for the first time. $^{13}$ In late April 1936 the British envoy in Prague, Joseph Addison, wrote to Foreign Secretary Anthony Eden, informing him that the Machník Decree became "subject of a complaint to the League of Nations by the Sudetendeutsche party". ${ }^{14}$ According to the British envoy, the SdP leaders had come to the conclusion that the aforementioned decision of the Minister of National Defence violated the rights of minorities contained in the peace treaty and was in contradiction to the Czechoslovak Constitution. The League of Nations should thus send an observer to Czechoslovakia in order to investigate the complaint, ${ }^{15}$ Addison said in the report. ${ }^{16}$

The British envoy, however informed the Foreign Secretary, that all the German parties were outraged by the Decree, i.e. including the Social Democrats, the Agrarians and others. He said in his report that all the parties were claiming unanimously that the Decree posed a threat to the existence of the entire German-speaking minority in Czechoslovakia.

10 See: Tisky poslanecké sněmovny, IV. volební období, 2. zasedání, 1936, tisk 288 (Naléhavá interpelace poslanců E. Kundta, dr H. Neuwirtha a R. Sandnera vládě, že ministerstvo národní obrany zadávajíc vojenské dodávky vydává výnosy a provádí úřední úkony odporující ústavě a smlouvě o ochraně menšin), 1.

11 http://www.law.muni.cz/sborniky/cofola2010/files/slabi/Horakova_Monika.pdf (23rd September 2013).

12 KOPECKÝ, 54.

13 More in detail cf. Lukáš NOVOTNÝ, Foreign Office, britské vyslanectví v Praze a sudetoněmecká otázka v roce 1936, in: Moderní dějiny: sborník k dějinám 19. a 20. století 19, 2011, 2, 156-158.

14 The National Archives, London, Kew (hereinafter referred to only as TNA), Foreign Office (hereinafter referred to only as FO) 371/20374, R 2430/32/12, Sir J. Addison to Mr. Eden, 27. 4. 1936, fol. 286.

15 Due to confusion in the use of precise legal terms on the sides of both complainants and defendants, regarding the "idiosyncratic practice of the League of Nations" in assessing complaints of ethnic minorities it is difficult to distinguish between the terms "complaint" and "petition", and they therefore both mean the same thing in the text. More in detail cf. René PETRÁŠ, Menšiny v meziválečném Československu. Právní postavení národnostních menšin v první Československé republice a jejich mezinárodněprávní ochrana, Praha 2009, 104.

16 TNA, FO 371/20374, R 2430/32/12, Sir J. Addison to Mr. Eden, 27. 4. 1936, fol. 286. 
Addison also added that the sorely tested population of the Sudeten German parts of the Republic would without any doubt "look to Great Britain in particular for an impartial examination of the complaint". ${ }^{17}$ Therefore, the initial reaction of the British envoy in Prague was clear and could give London the impression that the Decree of the Ministry of National Defence had prescriptive nature and meant a threat for Czech Germans.

The wording of the Decree, i.e. the calls of the Ministry lead by František Machník, was unfortunate. It indeed stated the obligation of replacing as soon as possible "ausländischen Angestellten durch inländische Kräfte tschsl. Nationalität". ${ }^{18}$ That was why the representatives of German parties taking part in the government opposed it as well. They found themselves in an uncomfortable situation. On the one hand being part of the government was only hardly compatible with the criticism of the Machník Decree. On the other hand, the requirement of not employing supporters of parties hostile to the Czechoslovak Republic was fully legitimate. The aim of the government in Prague was to make businesses assuring military contracts employ citizens of each nationality with respect to the proportional representation of national populations in the respective region. The purpose of the action was to avoid having Germans working on building fortifications on the German border, as these workers could give away information, whether it would be unconscious or rather conscious. ${ }^{19}$

The situation became dramatic in early March 1936, it also came to an answer to the government members' question time by the SdP, at which the Prime Minister's performance was not quite impressive. The parliamentary group of the strongest German party complained in early February on the aforementioned calls by the Ministry of National Defence and noted that they these violated the constitution and the Minority Treaty. The authors of the questions (MPs Ernst Kundt, Hans Neuwirth and Rudolf Sandner) also stated that the Ministry was deliberately aiming at layoffs of German workers and that the act was attacking German entrepreneurs. They also added that the Ministry's policy was leading to the discrimination of workers and clerks on the sole basis of their nationality, which was, in their view, unacceptable especially in the times of economic crisis. ${ }^{20}$ Then they asked the Prime Minister whether it was an arbitrary step of one ministry or a measure approved by the whole government and if so, whether the measure was in accordance with the constitutional order of the Czechoslovak Republic and whether the Prime Minister was willing to order an immediate withdrawal of the mentioned instructions of the Ministry of National Defence. ${ }^{21}$

\section{Ibidem.}

18 Tisky poslanecké sněmovny, IV. volební období, 2. zasedání, 1936, tisk 288 (Naléhavá interpelace poslanců E. Kundta, dr H. Neuwirtha a R. Sandnera vládě, že ministerstvo národní obrany zadávajíc vojenské dodávky vydává výnosy a provádí úřední úkony odporující ústavě a smlouvě o ochraně menšin), 1.

19 Cf. TNA, FO 371/20374, R 2430/32/12, Sir J. Addison to Mr. Eden, April 27, 1936, fol. 286. It was mainly the Ministry of National Defence who insisted on verifying the "state and civil reliability" of all involved. Indeed, there was certain "evidence that the Nazis (and now the SdP supporters) are working for the benefit of Hitler's Germany also as spies, volunteer agents and so on". Zdeněk KÁRNíK, České země v éře První republiky (1918-1938). Díl třetí. O přežití a o život (1936-1938), Praha 2003, 77.

20 Tisky poslanecké sněmovny, IV. volební období, 2. zasedání, 1936, tisk 288 (Naléhavá interpelace poslanců E. Kundta, dr H. Neuwirtha a R. Sandnera vládě, že ministerstvo národní obrany zadávajíc vojenské dodávky vydává výnosy a provádí úřední úkony odporující ústavě a smlouvě o ochraně menšin), 2-3.

21 lbidem, 3-4. 
The government's response hold on the MPs waiting for more than a month. The introduction of the reply provided only a vague statement: "Es ist das besondere Bestreben der Regierung, in allen von der Arbeitslosigkeit betroffenen Gebieten der Republik Arbeit zu beschaffen und die Not der Bevölkerung zu lindern; in dieser Richtung widmet die Regierung allen Bewohnern und Gegenden ohne Unterschied der Nationalität die gleiche Fürsorge. In diesen Intentionen gehen alle Ressorts vor und in der gleichen Weise geht auch das Ministerium für nationale Verteidigung vor, wenn es Lieferungen im grössten Ausmasse, soweit dies allerdings die Finanzmittel gestatten, ausschreibt und vergibt. Die Lieferungen werden in allen Gegenden aufgeteilt." 22 In his answer, the Prime Minister did not deny the existence of the calls and further wrote that the situation was to be adjusted in a natural way and nobody was to be dismissed, especially not members of minorities: "Man kann daher nicht von einer Verletzung der geltenden Gesetze oder von einer Verletzung der durch die Friedensverträge gewährleisteten Minderheitsrechte sprechen." 23 The situation in Czechoslovakia grew even more difficult in the international relations context. The Foreign Office officials were not the only ones to interfere with domestic affairs of Czechoslovakia after 1936 (e.g. the Permanent Under-Secretary of State at the Foreign Office Robert Vansittart). Along with the British Legation in Prague; with its complaint, the SdP had also drawn the League of Nations into the dispute. The authors of the complaint mainly pointed out the deliberate exclusion of German businesses from state contracts. According to a Foreign Office statement, Great Britain could not yet comment on the complaint, as it was not a member of the committee charged with the complaint. ${ }^{24} \mathrm{How}$ ever the appointed ministerial official did not refrain from noting, without even seeing the complaint, that the document was without any doubt "well founded" and that "the Czech government know already what our view is".25

On May 23, 1936, envoy Addison sent another report on the political situation in Czechoslovakia. In his report he informed the Foreign Office on the situation in the neighbouring countries, where the current political situation in Czechoslovakia had been following with concerns. The government, aware of the adverse publicity brought about by the publication of the Sudeten German complaint addressed to the League of Nations, decided to give another example of its co-operation or prove its co-operation with another example with Sudeten Germans, the British envoy wrote. ${ }^{26}$ According to his report, the government in Prague had firmly decided not to put into practice the Machník Decree. ${ }^{27}$ Similar and

22 Tisky poslanecké sněmovny, IV. volební období, 3. zasedání, 1936, tisk 339 [Odpověd' vlády na naléhavou interpelaci poslanců E. Kundta, dra H. Neuwirtha a R. Sandnera, že ministerstvo národní obrany zadávajíc vojenské dodávky vydává výnosy a provádí úřední úkony odporující ústavě a smlouvě o ochraně menšin (tisk 288)], 1.

23 Ibidem.

24 That, however, changed in May 1936. "Starting from this May until September, [Foreign Secretary] Eden will be the chair of the Council of the League of Nations, Committee of Three will be therefore presided by Englishman Malkin." Petráš, 113. Sir Herbert William Malkin was Foreign Office's legal adviser. Statements of British politicians also made it clear they would like to close the issue during London's presidency.

25 TNA, FO 371/20374, R 2430/32/12, Sir J. Addison to Mr. Eden, 27. 4. 1936, fol. 285. Foreign Office officials hoped to obtain at least a copy of the complaint in question.

26 TNA, FO 371/20374, R 3118/32/12, Sir J. Addison to Mr. Eden, 23. 5. 1936, fol. 305.

27 In October 1936, the regulation was revoked. 
even more effective powers were given to the government by the Act on State Defence ${ }^{28}$ passed by both Houses of Parliament, Addison reported. ${ }^{29}$ The British envoy was shocked by the provisions of the law and accused the government of acting as "both judge and jury". 30

In May 1936, a year after the creation of the SdP and after the following parliamentary election, the SdP representatives could declare that they had passed a successful period when it came to the presentation of their matter in Great Britain. With the substantial assistance from the British Legation in Prague, they succeeded in further convincing the leaders of the Foreign Office that the Czechoslovak policy dealing with German minority was unfair. The joint criticism of British diplomats in Prague and the Sudeten German leaders especially pointed out President Edvard Beneš. The SdP eventually also obtained internationalization of the issue by complaining about the Machník Decree to the League of Nations. That meant a substantial conclusion for London: an initially uninteresting and marginal ethnic issue in a state in Central Europe started to gain importance and intensity and had the potential of causing complications in promoting Great Britain's interests, as one of the interest pillars of Great Britain was to keep stability in the Central European region. ${ }^{31}$

In early July 1936, the Sudeten German complaint about the Machník Decree made itself felt again. William Strang, the head of the League of Nations section at the Foreign Office, received a letter from the League of Nations Secretariat informing him that Czechoslovak permanent representative at the League of Nations Rudolf Künzl-Jizerský asked for an extension of the time given to the Prague government to comment on the complaint. The sender of the letter asked Great Britain about its opinion, i.e. the opinion of its representative charged with the request. ${ }^{32}$

One-sided information from the British Legation in Prague on the development of Czech-German relations combined with the events connected to the Sudeten German complaint swayed the opinion of the Foreign Office to the disadvantage of Czechoslovakia. Robert Vansittart even charged the British Legation's Secretary in Prague Robert Hadow with drafting a memorandum bringing the most up-to-date information about the state of the Sudeten German issue in Czechoslovakia. The diplomat opened the document, which was quite in line with the focus and views of previous reports from the delegation in Prague, with a statement saying that the future of the Sudeten German movement

28 The Act on State Defence from May 13, 1936 stipulated that in businesses important for the defence of the state no persons unreliable for the state might be employed. The business owner had the obligation to lay off an employee immediately after getting the information that the employee in question had been established as a person unreliable for the state in an official decision which had come into force. More in detail cf. Sbírka zákonů a nařízení státu československého, 1936, 479-541.

29 The envoy was wrong. The law was passed by the Chamber of Deputies as early as on April 30 1936, and it was subsequently approved by the Senate on May 13. The law came into force on 23 June 1936.

30 TNA, FO 371/20374, R 3118/32/12, Sir J. Addison to Mr. Eden, 23. 5. 1936, fol. 305.

31 That stability allowed Great Britain to concentrate on their real interests. Rainer FRANKE, London und Prag. Materialien zum Problem eines multinationalen Nationalstaates 1919-1938, München - Wien 1982, 278.

32 TNA, FO 371/20374, R 3852/32/12, Mr. Strang (at Geneva) Communicated, 1. 7. 1936, fol. 389. See copy of the Sudeten German complaint ibidem, fol. 390-392. The authors of the petition complained of a violation of the Minority Treaty from September 1919 and of the regulation of the Ministry of National Defence from January 28, 1936. They claimed to be Czechoslovak citizens of German nationality representing $70 \%$ of Germans in Bohemia and Moravia. 
depended "upon an impartial investigation by the 'Committee of Three' of the Sudeten Deutsche petition to the League of Nations". Hadow later added that the result of the discussions would also affect the fate of Konrad Henlein. ${ }^{33}$

The memorandum went on in a passage on the Machník Decree, complained about by the Sudeten German in Geneva. The document said that the government had indeed decided to put off the legal force of the Decree; that was, however, in the view of the British diplomat, amply compensated with the Act on the State Defence, which guaranteed the government broader powers. Hadow, therefore, fully identified with the sentiment of envoy Addison, who had come to a similar conclusion already in late May 1936. ${ }^{34}$

The Sudeten German complaint about the Machník Decree occured again in September 1936. ${ }^{35}$ Nicholas J. A. Cheetham from the Foreign Office assessed the Czechoslovak government's response to the complaint and divided it into two parts: the factual one and the legal one. He qualified the former as "a very lame attempt to prove that the Machník Decree did not necessarily imply discrimination against Sudetendeutsche employees and to justify it on grounds of national security". ${ }^{36}$ The legal arguments were, in his opinion, based on the disagreement whether the document was actually a petition or not; as in the view of the Czechoslovak government ${ }^{37}$ a subject of a petition could only be "a law, a Decree or a règlement officiel but it cannot be a letter written by a Ministry to a firm". Based on the available information, the Foreign Office, however, came to the conclusion that these letters actually represented an official action of the Czechoslovak government. ${ }^{38}$ Regarding that, the Foreign Office was mistaken. A letter from any Ministry cannot have any official status, unless it becomes a law or at least a regulation by the whole government.

Based on that view, London proceeded to discuss the whole issue which had an unpleasant undertone. Great Britain, i.e. its representative, presided the Committee of Three ${ }^{39}$ at that time, but the Foreign Office had been expecting from the start: " [...] it proved impossible under the league's rigid minorities procedure to contend that the Minorities Treaty had been violated, particularly since the Czechs argued that the Machník Decree had been

33 TNA, FO 371/20374, R 3946/32/12, Foreign Office Memoradum (Mr. R. H. Hadow), 8. 7. 1936, fol. 11. He repeated his opinion that Henlein was willing to cooperate with Czechoslovakia and he also reiterated his criticism of President Beneš, writing that: "Since Benes became President the position of Sudeten Deutsche has become infinitely worse."

34 Cf. ibidem, fol. 11-12.

35 The petition delivered to Geneva in April 1936 contained a complaint by the Sudetendeutche and Karpatendeutsche Party (the party was created by merging the SdP and the Karpatendeutsche Party in November 1935 , the leader of the new political entity was Konrad Henlein) of the Machník Decree, which in their opinion violated all the rights of minorities contained in the peace treaty and was contradictory to the Czechoslovak Constitution. The Czechoslovak representative at the League of Nations received the petition in May and sent it back to the government in Prague for comments. On the last day of August 1936 the Czechoslovak government sent their comments on the complaint.

36 TNA, FO 371/20375, R 5296/32/12, 8. 9. 1936, fol. 154.

37 The government claimed that the Machník Decree was not a normative Decree of the Ministry of National Defence, the letters forming the Decree were, according to Prague's opinion, in themselves no law or other regulation. PETRÁŠ, 239, 240.

38 TNA, FO 371/20375, R 5296/32/12, 8. 9. 1936, fol. 154.

39 More in detail cf. Andrej TÓTH - Lukáš NOVOTNÝ - Michal STEHLÍK, Národnostní menšiny v Československu 1918-1938. Od státu národního ke státu národnostnímu?, Praha 2012, 230-231, footnote 196. 
withdrawn and Henlein brought forward no new petition to demonstrate, as Addison believed, that the Machník Decree had simply been replaced by other equally discriminatory measures". ${ }^{40}$

The opinion of the Foreign Office to the case of the Machník Decree was presented on October 1, 1936 in The Times in an article inspired by Robert Vansittart on the Sudeten German petition to the League of Nations. The author highlighted both the importance of Sudeten Germans for Czechoslovakia and the SdP's moderation. In prudent words, the article pointed out the disadvantage faced by the German minority and President Benešs promises to eliminate the drawback. Had good will been shown, the rivalry between the two nations could be overcome, the author added. ${ }^{41}$ It was evident that London was still considering the SdP as a moderate political party and preferred an agreement between the party and the Czechoslovak government.

The problem of the Ministry of National Defence's calls itself shows the practice the office followed when commissioning state contracts; it was not a political conception of the government, not because such a policy would have been contradictory not only to its international commitments adopted after First World War, but also to the constitution. In this case it was more of a "faux pas by the Ministry, which leaked to the public and even in a written form [...]". ${ }^{42}$ Above all, the Machník Decree deteriorated the Czech-German relations and involved Great Britain in the solution, which led to increased activity of the British Legation in Prague.

In the autumn of 1936, it had been proven that the Machník Decree did not have the character of a binding government regulation (as Foreign Minister Krofta informed Heinrich Rutha in November), ${ }^{43}$ the SdP representatives decided to amend their petition in order to be able to complain about the Czechoslovak government again. However, Krofta informed the SdP representatives that such actions only hinder a potential future mutual agreement. ${ }^{44}$ But Rutha still confirmed to the British envoy Charles Bentinck that the party was going to file a new petition, but was still waiting to see the upcoming events events. ${ }^{45}$ The Foreign Office's legal advisor Herbert W. Malkin came to the conclusion at the beginning of January 1937 that the SdP should complain again, the object of their interest would be selected provisions of the Act of State Defence, or at least that was what he had learnt from the representatives of the party at their meeting in Geneva. He also added that due to the

40 CORNWALL, 329. In the following year, the SdP lost interest in filing further complaints at the League of Nations. Envoy Addison informed London already in 1936 that the government would not put the Machník Decree into practice, as the Act on State Defence provided it with equal and even more effective powers. Despite that the petition appeared on the agenda of the Committee of Three and aroused lively discussion amongst diplomats of the Foreign Office. Cf. e.g. TNA, FO 371/20375, R 5599/32/12, United Kingdom Delegation (League of Nations), 21. 9. 1936, fol. 196-200; R 5819/32/12, United Kingdom Delegation, (Geneva), 28. 9. 1936, fol. 210-213; R 5827/32/12, United Kingdom Delegation (Geneva), 30. 9. 1936, fol. 214-219; R 6029/32/12, United Kingdom Delegation (Geneva), 9. 10. 1936, fol. 231-235.

41 FRANKE, 282.

42 PETRÁŠ, 241.

43 TNA, FO 371/21125, R 209/154/12, telegram from Mr. Bentinck (Prague), 8. 1. 1937, fol. 10. The Minister of the National Defence confirmed that himself at the budget committee of the Chamber of Deputies.

44 KOPECKÝ, 55.

45 TNA, FO 371/21125, R 209/154/12, telegram from Mr. Bentinck (Prague), 8. 1. 1937, fol. 10. 
circumstances, there was no point in bringing the current petition forward to the League of Nations. ${ }^{46}$

In late January 1937, the SdP's petition against the Machník Decree was again on the agenda of the Committee of Three. According to Herbert W. Malkin, its members agreed that the best solution of the current situation (the de facto invalidity of the Decree) was to wait until the next meeting of the League of Nation's Council. The Committee's members also expressed their concerns about the fact that they did not actually know the exact legal status of the Decree. Therefore, they decided to turn to the director of the minority section of the League (the post was occupied by Danish Peter Christian Schou at the time) and ask him to discretely find out from the Czechoslovak representative in Geneva, Rudolf Künzl-Jizerský, what was the actual relevance of the Decree. Malkin wrote in details about his meeting with the Czechoslovak representative, who was according to Malkin very upset and required the petition to be closed "without more ado". ${ }^{47}$

In early 1937, the situation developed in a peculiar way. There were proceedings going on at the corresponding level in Geneva concerning the SdP's petition against the Machník Decree, which had, however, not become a part of Czechoslovak legislation, a fact that was known to both the complainants (who even considered filing a new petition) and the representatives of Prague at the League of Nations. Members of the Committee of Three, nothwithstanding, groped in the dark and asked for further specifications on the legal status of the ministerial Decree. In mid-February, it was clear to the British representative at the League that the petition had to be put aside, by reason of the expiration. ${ }^{48}$ In early March, Owen O'Malley, the head of the Southern Department at the Foreign Office stated in his notice to the British Legation's Secretary in Prague, Robert Hadow, that under the given circumstances there was no other option than to close the discussions on the petition. As its fate had been open from previous October, the SdP representatives had had enough time to negotiate with the Czechoslovak government, O'Malley added. ${ }^{49}$ By that he exposed at least one of the motives of the British diplomacy - the opportunity of exerting unofficial pressure on Prague to come to an agreement with Sudeten Germans.

At the beginning of April 1937 the head of the Southern Department had the chance to speak with Peter Schou; the subject of the discussion was the Sudeten German complaint and British attitude towards it. Owen O'Malley did not understand why the SdP was hesitating about filing another petition. The director of the Minority Section of the League explained that with Germany's influence over the policies of the SdP: from Berlin's point of view, it was useless to ask anything from Geneva. O'Malley thought that was exaggerated. On the contrary, he was not surprised by the attitude of the Czechoslovak government: Prague did not want the Committee of Three to conclude that the petition was unfounded and the Machník Decree to be withdrawn. In that case, the head of Southern Department

46 Ibidem, fol. 9.

47 TNA, FO 371/21127, R 684/188/12, United Kingdom Delegation, Geneva, 28. 1. 1937, fol. 131. Malkin added he did not expect the issue to be concluded before the meeting of the Council of the League of Nations in May. Even Orme Sargent, head of the Central Department at the Foreign Office understood that unless the SdP representatives present new evidence, the petition would be rejected. Cf. ibidem, 15. 2. 1937, fol. 127-128.

48 Cf. TNA, FO 371/21127, R 1174/188/12, Mr. Hadow (Prague), 17. 2. 1937, fol. 314.

49 Ibidem, 5. 3. 1937, fol. 315-316. 
believed, it would make the impression that the document had not come into force because it had been contrary to the Minority Treaties. ${ }^{50}$

However, that was refused by Czechoslovakia; it had been claiming since the beginning that such a Decree could not have the normative status of a law or a government regulation; and therefore, required the petition not to be discussed on the basis of its factual pointlessness. That had been since the beginning the substantive argument between the Czechoslovak government and the SdP on the interpretation of the petition's sense. Prague claimed that there was nothing to talk about, while the representatives of the strongest Sudeten German party held the view that the Machník Decree violated the minority commitments made by Czechoslovakia after 1918.

A few days later (April 12) the new British envoy in Prague Basil Newton sent Foreign Secretary Anthony Eden a memorandum written by Robert Hadow on the current status of the SdP and its relation towards Czechoslovakia, adding that "the information in the memorandum is derived from a variety of sources and good will, it is hoped, to be of assistance in judging the attitude to be adopted towards the question of closing the petition against the Machník Decree [...]". ${ }^{51}$ Hadow's memorandum opened with a plain statement that after the adoption of the Act on State Defence the Machník Decree became redundant. The Secretary of the British Legation then added that provisions of the act provide the Czechoslovak government with all the powers for dealing with citizens unreliable for the state. He also complained about Prague's unwillingness to proceed to serious talks with the SdP, manifested e.g. in the proposal of the February Agreement. ${ }^{52}$ In his document, Hadow continued his criticism of the Czechoslovak government's policy towards the Sudeten German minority, i.e. the SdP, and made no more comments on the Machník Decree. On May 6, 1937 a Foreign Office official R. C. Skrine Stevenson wrote to Frank Walters at the Secretariat of the League of Nations that London had more or less come to terms that the SdP's petition would be definitively closed at the nearest meeting of the Committee of Three. ${ }^{53}$ In early May it was clear that London closed the affair with the SdP's petition against the Machník Decree. It was obvious that Geneva would be satisfied with a formal explanation by the Czechoslovak government and that the SdP was not going to file another complaint for the time being. ${ }^{54}$

Prague made a statement concerning the petition in early May 1937. On May 10, Peter Christian Schou announced to Herbert Malkin that the Czechoslovak delegation in Geneva would shortly hand him a document proving that the Machník Decree was officially

50 TNA, FO 371/21128, R 2375/188/12, Foreign Office Minute (Mr. O’Malley), 7. 4. 1937, fol. 127.

51 TNA, FO 371/21128, R 2572/188/12, Mr. Newton (Prague), 12. 4. 1937, fol. 137.

52 Ibidem, fol. 139-140. More in detail about February Agreement cf. TÓTH - NOVOTNÝ - STEHLíK, 352-355, 380-383; Jörg KRACIK, Die Politik des deutschen Aktivismus in der Tschechoslowakei 1920-1938, Frankfurt am Main, Berlin, Bern, New York, Paris, Wien 1999, 344-345. It was the existence of the February Agreement which helped to explain that Prague was seeking an agreement with Sudeten Germans and that the Decreee of Minister of National Defence had not been meant as a discriminatory measure. DEJMEK, Nenaplněné naděje, 326.

53 TNA, FO 371/21128, R 2572/188/12, 6. 5. 1937, fol. 150-151. Cf. also TNA, FO 371/21128, R 2900/188/12, Foreign Office Minute (Sir W. Malkin), 27. 4. 1937, fol. 184.

54 Complaints about new injustices against Sudeten Germans, raised by Heinrich Rutha in Karlsbad on April 12, 1937, were considered by the British Legation in Prague as mere verbal threats. Cf. TNA, FO 371/21128, R 2609/188/12, Prague Chancery (to Southern Department), 13. 4. 1937, fol. 167. 
invalid. ${ }^{55}$ A day later, Frank Walters wrote to Ralph Stevenson to inform him that he had learnt from a reliable source that the SdP had duly noted the end of the discussions on its petition and that it was probably not going to file a new complaint. The British representative in the Secretariat of the League of Nations added that the SdP did not dispose of any legal means to prevent the removal of the petition and that it did not even surprise its representatives. ${ }^{56}$ Frank Walters' statement showed clearly that leaders of the SdP conceived their petition against the Machník degree; rather it was a means to raise their own visibility. At the beginnign of May 1937 aborted the "life" of the Sudeten German complaint about the Machník Decree. Under the pressure of circumstances (clear stance of the Czechoslovak government, the unofficial character of the ministerial Decree and last, but not least, the unwillingness or incapability of the SdP to put forward further relevant evidence) the Committee for Minority Issues of the League of Nations eventually stated that the complaint was solved by the explanation of the Czechoslovak government and declared it to be unfounded. At the end of May the Prager Tagblatt also informed on the end of the affair, reporting that the decision of the Committee of Three caused no surprise in Prague. "In their reaction to the complaint, the Czechoslovak government took the stance that the Machník Decree had never existed"; the paper only confirmed the Cabinet's opinion that the whole petition affair had been useless. ${ }^{57}$

The effect of the Sudeten German complaint about the Machník Decree on the German-Czech relations was rather ambivalent. On the one hand, the discussions on the petition did not have any actual effect on the existing situation in Czechoslovakia, ${ }^{58}$ the League of Nation's Council was satisfied with the formal explanation of the Czechoslovak government that the Decree had not turned into a part of legislation in force. On the other, the whole problem became international and the Sudeten Germans succeeded in involving Great Britain. ${ }^{59}$ On the one hand, it can be said that the Czechoslovak government achieved a partial success, if we accept that the Committee of Three, or the League of Nation's Council, did not find any violations of the commitments adopted in 1919. On the other hand, it turned out that the old practice of the 1920s, when Sudeten Germans complained about violations against minority commitments of the Czechoslovak Republic, had resurfaced. The times had, however, changed, the Sudeten German Party used the complaint above all as a means of raising awareness of the German-Czech relations at international level.

55 TNA, FO 371/21128, R 3292/188/12, M. Schou (League of Nations) to Sir W. Malkin, 10. 5. 1937, fol. 216. 56 TNA, FO 371/21128, R 3262/188/12, Mr. Walters (League of Nations) to Mr. Stevenson, 11. 5. 1937, fol. 213-214.

57 TNA, FO 371/21129, R 3750/188/12, Mr. Newton (Prague), 26. 5. 1937, fol. 256. Meetings of the Committee of Three (Foreign Ministers of Great Britain, Latvia and Sweden) on the petition, May 25, 1937, see ibidem, R 3797/188/12, United Kingdom Delegation (Geneva), 29. 5. 1937, fol. 260-261.

58 Even though the Machník Decree finally did not come into force and the SdP did not file more complaints at the League of Nations,

59 Henlein and other The SdP leaders rather hoped "that the petition might end up on the agenda of the League Council, and result in major international pressure upon Prague". Mark CORNWALL, 'A Leap into Ice-Cold Water': The Manoeuvres of the Henlein Movement in Czechoslovakia 1933-1938, Mark CORNWALL, Robert John Weston EVANS (eds.), Czechoslovakia in a Nationalist and Fascist Europe 1918-1948, Oxford, New York 2007, 139. 


\begin{abstract}
The study is based on unpublished documents of the National Archives in London and deals with the perception of the so-called Machnik's Decree from the point of view of the British Legation in Prague and the Foreign Office. The so-called Machnik's Decree means the appeals of the Czechoslovak Ministry of National Defence from January 1936, addressed to various enterprises who were interested in state contracts. These contracts required the trustworthy persons only. Both British Legation and the Foreign Office found such activities inappropriate and understood them to be useless. The whole affair, which was discussed on the field of League of Nations, helped the Sudeten German Party to gain publicity on the international groun
\end{abstract}

\title{
Keywords
}

Machnik Decree, Sudeten German Party, First Czechoslovak Republic, national minorities, Foreign Office, British Legation in Prague 